\title{
Interactions of Glutamatergic Neurotransmission and Brain-Derived Neurotrophic Factor in the Regulation of Behaviors after Nicotine Administration
}

\author{
Jieun Kim ${ }^{1}$, Ju Hwan Yang ${ }^{1}$, In Soo Ryu ${ }^{1,2}{ }^{1}$, Sumin Sohn ${ }^{1}$, Sunghyun Kim ${ }^{1}$ and \\ Eun Sang Choe ${ }^{1, *}$ \\ 1 Department of Biological Sciences, Pusan National University, 63-2 Busandaehak-ro, Geumjeong-gu, \\ Busan 46241, Korea; jieun0479@pusan.ac.kr (J.K.); juhwanyang@pusan.ac.kr (J.H.Y.); \\ insoo.ryu@kitox.re.kr (I.S.R.); soomin@pusan.ac.kr (S.S.); s.hyun@pusan.ac.kr (S.K.) \\ 2 Research Center for Safety Pharmacology, Korea Institute of Toxicology, 141 Gajeong-ro, Yuseong-gu, \\ Daejeon 34114, Korea \\ * Correspondence: eschoe@pusan.ac.kr
}

Received: 7 May 2019; Accepted: 14 June 2019; Published: 16 June 2019

\begin{abstract}
Nicotine causes tobacco dependence, which may result in fatal respiratory diseases. The striatum is a key structure of forebrain basal nuclei associated with nicotine dependence. In the striatum, glutamate release is increased when $\alpha 7$ nicotinic acetylcholine receptors expressed in the glutamatergic terminals are exposed to nicotine, and over-stimulates glutamate receptors in gamma amino-butyric acid (GABA)ergic neurons. These receptor over-stimulations in turn potentiate GABAergic outputs to forebrain basal nuclei and contribute to the increase in psychomotor behaviors associated with nicotine dependence. In parallel with glutamate increases, nicotine exposure elevates brain-derived neurotrophic factor (BDNF) release through anterograde and retrograde targeting of the synapses of glutamatergic terminals and GABAergic neurons. This article reviews nicotine-exposure induced elevations of glutamatergic neurotransmission, the bidirectional targeting of BDNF in the striatum, and the potential regulatory role played by BDNF in behavioral responses to nicotine exposure.
\end{abstract}

Keywords: glutamate receptor; neurotrophic factor; nicotine dependence; TrkB; striatum

\section{Introduction}

Nicotine is a major constituent of the tobacco plant and commercial cigarettes, and is considered to be the cause of compulsive tobacco smoking [1,2]. Nicotine delivered to the striatum increases extracellular dopamine and glutamate concentrations by stimulating nicotinic acetylcholine receptors (nAChRs) [3-6]. An increase in the level of extracellular dopamine in the striatum in turn increases glutamate release by stimulating basal ganglia [7-9]. Resulting elevated glutamate levels stimulate ionotropic- and metabotropic glutamate receptors (iGluRs and mGluRs) expressed in striatal gamma amino-butyric acid (GABA)ergic neurons [10-12]. These stimulations cause short- and long-term changes in neuronal activities and gene expressions and cause behavioral changes by upregulating GABAergic outputs to other parts of basal ganglia $[7,13,14]$.

Nicotine exposure upregulates expression of brain-derived neurotrophic factor (BDNF) in glutamatergic terminals and GABAergic neurons of the striatum [15-17]. Furthermore, evidence demonstrates that BDNF gene expression is upregulated by increased glutamate release in the striatum [16,18-20]. Cleaved BDNF is the most abundant neurotrophic factor in the brain and binds to mature-BDNF-activated tropomyosin receptor kinase B (TrkB) and pro-BDNF-stimulated p75 receptors [21-23]. This study was undertaken to review spatiotemporal interactions of glutamate 
and BDNF in the striatum that modulate psychomotor and nicotine-seeking behaviors in response to nicotine exposure.

\section{The Striatum Potentiates Glutamate Release after Nicotine Administration}

In the human brain, the striatum is a key structure of forebrain basal ganglia and is composed of dorsal and ventral striatum. The dorsal striatum is comprised of the caudate nucleus and putamen $(\mathrm{CPu})$, and the ventral striatum of the nucleus accumbens (NAc) [8,24]. The $\mathrm{CPu}$ receives dopaminergic inputs from the substantia nigra pars compacta in the midbrain and glutamatergic inputs mainly from the somatosensory cortex $[24,25]$. On the other hand, the NAc receives dopaminergic inputs from the ventral tegmental area (VTA) in the midbrain and glutamatergic inputs from the prefrontal cortex (PFC) [25]. GABAergic medium spiny neurons constitute $>90 \%$ of the striatum, integrate glutamatergic and dopaminergic inputs, and potentiate glutamatergic response when a drug of abuse is administered [7,24,25].

Previous studies have shown chronic administration of nicotine increases extracellular dopamine concentrations in rat striatum [26]. Other studies have shown that dopamine release is increased by the local infusion of nicotine into the $\mathrm{CPu}$ and NAc as determined by in vitro fast-scan cyclic voltammetry analysis [27]. Repeated nicotine exposure increases extracellular glutamate concentrations in rat $\mathrm{CPu}$ and NAc as determined by real-time glutamate biosensing and microdialysis $[13,27]$. Chronic administration of nicotine increases dopamine release in the striatum $[27,28]$. Systemic repeated exposure to nicotine dose-dependently increases dopamine levels in the CPu and NAc [29], and that local infusion of nicotine increases glutamate release in the striatum $[6,30]$. These findings suggest that nicotine administration potentiates glutamate release in the GABAergic neurons of the striatum by integrating dopaminergic neurotransmission.

\section{Stimulation of $\alpha 7 \mathrm{nAChRs}$ in the Striatum is Required for Glutamate Release}

$\mathrm{N}$-AchRs are a heterogeneous family of pentameric ion channels ubiquitously expressed in the central nervous system [31-33]. They are composed of eight $\alpha(\alpha 2-7,9,10)$ and three $\beta(\beta 2-4)$ subunits which include heteromeric $(\alpha 4)_{3}(\beta 2)_{2},(\alpha 4)_{2}(\beta 2)_{3},(\alpha 3)_{2}(\beta 4)_{3}, \alpha 4 \alpha 6 \beta 3(\beta 2)_{2}$, and homomeric $(\alpha 7)_{5}$ [31-33]. Striatal exposure to nicotine by cigarette smoking binds and stimulates $\alpha 4 \beta 2$ and/or $\alpha 7 \mathrm{nAChRs}$ and increases glutamate release [32,34]. Numerous studies have demonstrated nicotine administration potentiates glutamate release by stimulating excitatory $\alpha 7 \mathrm{nAChRs}$ dominantly expressed in glutamatergic terminals of the striatum [6,35-37]. For instance, blockade of $\alpha 7 \mathrm{nAChRs}$ decreases increases in glutamate release in the $\mathrm{CPu}$ induced by repeated nicotine exposure [13]. Whereas blockade of $\alpha 4 \beta 2 \mathrm{nAChRs}$ reduced the nicotine-induced increase in dopamine release in the $\mathrm{CPu}$ and NAc $[27,29]$. These findings suggest $\alpha 7 \mathrm{nAChRs}$ stimulation plays a crucial role in enhancing striatal glutamate release, and this suggestion is supported by finding that blockade of $\alpha 7$ or $\alpha 4 \beta 2 \mathrm{nAChRs}$ in the CPu by local infusion of the receptor antagonist, methyllycaconitine (MLA) or dihydro- $\beta$-erythroidine $\mathrm{Dh} \beta \mathrm{E}$, respectively, reduced the nicotine-induced increase in glutamate release [6]. It has also been reported that $\alpha 7 \mathrm{nAChRs}$ blockade reduced the nicotine-induced increase in glutamate release in the $\mathrm{CPu}$ innervating neurons from the PFC $[5,38,39]$. However, the stimulation of $\alpha 4 \beta 2 \mathrm{nAChRs}$ in the CPu by indirect glutamate release caused by stimulating dopaminergic systems via basal ganglia in the forebrain has not been elucidated. Together, these findings suggest $\alpha 7$ stimulation is responsible for potentiating glutamate release in the $\mathrm{CPu}$ and upregulating GABAergic outputs to basal ganglia.

Repeated systemic injections of nicotine were found to increase behavioral sensitization, as determined by assessing locomotor and stereotypy activities [13]. Furthermore, a challenge injection following repeated exposure to nicotine also showed increased behavioral sensitization [13]. This increase in behavioral sensitization was reduced by pharmacological blockade of $\alpha 7 \mathrm{nAChRs}$ in the $\mathrm{CPu}$ of rats [13]. Similarly, anxiety-like behaviors caused by nicotine withdrawal were attenuated by $\alpha 7 \mathrm{nAChR}$ blockade in mice [40]. In addition, motivation induced by nicotine self-administration in 
rats was reduced by $\alpha 7 \mathrm{nAChR}$ blockade induced by intra-NAc infusion of the receptor antagonist, PNU282987 [41]. Taken together, these findings suggest nicotine-induced $\alpha 7 \mathrm{nAChR}$ stimulation in the striatum is required to sensitize psychomotor behaviors, such as locomotor and stereotype activities.

\section{Stimulation of Glutamate Receptors in GABAergic Output Neurons Increases Behavioral Sensitization and Nicotine-Seeking Behavior}

Elevation of glutamate release due to $\alpha 7 \mathrm{nAChR}$ stimulation over-stimulates glutamate receptors in GABAergic neurons of the striatum [42]. Two families of glutamate receptors expressed in the striatum are iGluRs and mGluRs [43-45]. Stimulation of the iGluRs, N-methyl-D-aspartate receptor (NMDAR), $\alpha$-amino-3-hydroxy-5-methyl-4-isoxazolepropionic acid receptor (AMPAR), and kainate receptor (KAR) in the striatum is known to upregulate $\mathrm{Ca}^{2+}$ and $\mathrm{Na}^{+}$conductance [43-46]. Previous studies have demonstrated that increased glutamate release in the striatum alters the functions of iGluRs [26,30]. Repeated nicotine administration increases the phosphorylation of the NMDAR GluNR2B subunit in the NAc [47,48]. Furthermore, electrophysiological recordings obtained from rat NAc reveals that local nicotine infusion increases NMDA currents in neurons [42,49]. These findings suggest that stimulation of iGluRs by elevated glutamate release after nicotine administration leads to changes in neuronal excitability and subsequent behavioral changes. This suggestion is supported by findings that increases in nicotine-seeking behavior in response to nicotine self-administration are associated with phosphorylation of the NMDAR GluNR2B and AMPAR GluR2 subunits in the NAc $[47,48]$. While blockade of NMDAR in the VTA suppresses the nicotine-induced increase in self-administration [50].

The mGluRs are classified into group I, II, and III in accord with the pharmacology and biochemistry of GTP-binding proteins [44]. Stimulation of mGluR5 linked to excitatory Gq, which is dominantly expressed in the striatum, upregulates the productions of inositol trisphosphate $\left(\mathrm{IP}_{3}\right)$ and diacylglycerol (DAG) via the hydrolysis of phospholipase C (PLC)-mediated phosphatidylinositol 4,5-bisphosphate $\left(\mathrm{PIP}_{2}\right)$ [44]. In turn, $\mathrm{IP}_{3}$ increases $\mathrm{Ca}^{2+}$ release from the ER, while DAG activates protein kinase $\mathrm{C}(\mathrm{PKC})$ and upregulates $\mathrm{Ca}^{2+}$ signaling cascades, and thus, induces behavioral changes [9]. Growing evidence shows that blockade of mGluR5 in the striatum reduces nicotine-induced increases in locomotor activity, motivation, conditioned place preference, and self-administration [51-54]. These findings support that stimulation of mGluR5 in the striatum by glutamate increase is required for nicotine-induced behavioral sensitization and nicotine-seeking behavior.

Group II (mGluR2/3) and III (mGluR4/6-8) expressed mainly in the necks of glutamatergic terminals are also stimulated by excessive glutamate release $[42,55,56]$. These receptors linked to inhibitory $\mathrm{G}_{\mathrm{i} / \mathrm{o}}$ control glutamate release by inhibiting adenylyl cyclase-mediated signaling cascades $[42,55,56]$. Previous studies have demonstrated stimulation of group II/III mGluRs attenuates nicotine-induced self-administration by reducing glutamate release in the CPu and NAc [57]. Pharmacological stimulation of these receptors or their potentiation by peptides, such as mGluR2 PAMs AZ8418, and AZD8529, in the medial forebrain reduces nicotine-induced increases in self-administration [58]. These findings suggest stimulation of group II/III mGluRs downregulates nicotine-induced increase in glutamatergic neurotransmission by reducing glutamate release in a feedback control manner.

\section{Nicotine Increases Bidirectional BDNF Release in the Striatum}

Nicotine increases BDNF expression in the striatum $[16,19,20]$, but the mechanisms responsible have not been elucidated. BDNF is constitutively transcribed and synthesized in the ER as a prepro-( $35 \mathrm{kDa})$, and pro-peptide ( $32 \mathrm{kDa}$ ) [59]. Rodent BDNF genes contain nine exons (I-IX) which include their own promoters [60]. The promoter region of exon IV contains three $\mathrm{Ca}^{2+}$-responsive element (CaRE1-3 also called CRE1-3), and interaction between CaRE3 and phosphorylated CREB increases the transcriptional activity of BDNF on promoter at exon IV of the BDNF gene and induces the translation of pro-BDNF [61]. 
Pro-BDNF is then proteolytically processed through the trans-Golgi network (TGN) by endopeptidases, such as the Golgi-resident- and secretory granule-resident proprotein convertases 1-7 (PC), or the membrane-anchored protein, furin [61,62]. Cleaved BDNF in vesicles associated with either PC or furin undergoes posttranslational modifications, such as $\mathrm{N}$-acetylation and carboxyl-terminal amination [63], which are transported to glutamate terminals. During this process, phosphorylated Huntingtin (htt), which is activated by a variety of TGN signaling cascades, recruits the motor proteins, kinesin 1 and dynein [64-66]. Binding of the htt complex to vesicles determines whether the targeting of cleaved BDNF is anterograde or retrograde [64-66]. Cleaved BDNF is known to be sorted by two different types of vesicles, that is, secretion vesicles and secretory granules, which are linked to furin and PC, respectively [61,62]. In addition, secretory granules contain TGN-originated sorting protein complex in which cleaved BDNF is released in a pH-dependent manner. Subsequent exocytosis triggered by the stimulation of $\alpha 7 \mathrm{nAChRs}$ by nicotine binding then results in the release of a mixture of pro- and mature-BDNF [23]. Released pro-BDNF is further regulated by endopeptidases, such as tissue-plasminogen activator (tPA) plasmin cascade or matrix-metalloproteinases (MMPs), which are located outside of neurons $[67,68]$. These extracellular enzymes convert pro-BDNF into mature-BDNF, which stimulates TrkB in striatal GABAergic neurons. However, not all pro-BDNF is converted to mature-BDNF [59].

Apart from anterograde BDNF release, cleaved BDNF is also constitutively transported to dendritic spines of GABAergic neurons via retrograde axonal transport. The stimulation of glutamate receptors by nicotine-induced glutamate release facilitates BDNF secretion into synaptic clefts [69]. Although the cellular mechanisms responsible for the retrograde release of BDNF from the dendritic spines in the striatum are not clear, they may involve increased $\mathrm{Ca}^{2+}$ influx due to iGluR stimulation $[70,71]$. Stimulation of mGluR5 may contribute to BDNF release by activating PLC-mediated $\mathrm{IP}_{3}$, which increases $\mathrm{Ca}^{2+}$ mobilization from the ER, and DAG, which activates PKC and increases $\mathrm{Ca}^{2+}$ conductance by stimulating NMDAR [72]. Furthermore, an increase in intracellular $\mathrm{Ca}^{2+}$ concentration may activate the SNAP REceptor (SNARE) proteins, synpatotagamin-6 (SYT6) and complexin, and facilitate the retrograde targeting of BDNF release [73].

\section{Nicotine Activates BDNF-Mediated TrkB Signaling Cascades in GABAergic Neurons}

BDNF released by either anterograde or retrograde targeting binds to its receptor tropomyosin receptor kinase $B(T r k B)$, also known as type 2 of neurotrophic tyrosine kinase [23], whereas pro-BDNF binds to p75 neurotrophin receptor (p75NTR), though it may be converted to mature-BDNF by MMPs [67]. Previous studies have shown nicotine increases BDNF levels and activates TrkB-mediated signaling cascades in GABAergic neurons [74]. Furthermore, BDNF infusion into the NAc stimulates TrkB phosphorylation [16], that is, binding of BDNF to TrkB results in the phosphorylations of tyrosine and serine of TrkB at positions Tyr515, Tyr816, and Ser478 [75]. Phosphorylation at Tyr515 is linked to Shc adaptor protein and activates the Pi3K/Akt pathway [76,77], and She activation upregulates Ras-signaling cascades [75]. The activation of Pi3K/Akt and Ras-signaling pathways leads to ERK phosphorylation [76,77], which in turn results in the phosphorylation of CREB and the activation of mammalian target of rapamycin (mTOR)-signaling cascades [75-77]. In addition, phosphorylation at Tyr816 creates a binding site for PLC $\gamma$, and TrkB-PLC $\gamma$ binding results in increases of $\mathrm{Ca}^{2+}$ release from the ER by activating $\mathrm{IP}_{3}$ [75]. This release of $\mathrm{Ca}^{2+}$ into the cytoplasm then activates a variety of $\mathrm{Ca}^{2+}$ signaling cascades, retrograde targeting of BDNF, and the upregulation of neuronal activity $[73,75]$. Ser478 located in the juxtamembrane region of TrkB is phosphorylated by cell division protein kinase 5 (CDK5), which activates Rac 1 that is involved in the BDNF-dependent remodeling of dendritic spines [75]. Signaling cascades emanating from TrkB phosphorylation lead to the synaptic remodeling of GABAergic neurons after nicotine exposure, which may act to downregulate or upregulate nicotine-induced behaviors depending on the conditions of nicotine exposure [78].

Unlike mature-BDNF, pro-BDNF facilitates interactions between p75NTR and several adaptor proteins, such as neurotrophin receptor-interacting factor (NRIF), melanoma-associated antigen 
(MAGE), neurotrophin receptor p75 interacting MAGE homologue (NRAGE), Schwann cell factor 1 (SC1), and RhoGDI [79], which function by activating the expression of pro-survival or pro-apoptotic genes [80]. However, it is unclear whether p75NTR-linked signaling cascades contribute to behavioral sensitization or nicotine-seeking behavior.

\section{BDNF Differently Regulates Behavior According to the Conditions of Nicotine Exposure}

Nicotine increases the anterograde and retrograde targeting of BDNF in striatal glutamate terminals and GABAergic neurons, respectively, and anterograde targeting of BDNF occurs in cortical neurons projecting to the striatum [81-84]. Evidence shows nicotine exposure induces the over-expression of BDNF $m R N A$ in cultured cortical neurons [84]. For example, chronic treatment with the nicotine analog, choline, increased the expression and release of BDNF from cultured cortical neurons [83]. Stimulation of $\alpha 7 \mathrm{nAChRs}$ in the SH-SY5Y cell line increased BDNF synthesis and secretion [82,83], whereas treatment with MLA, an $\alpha 7 \mathrm{nAChR}$ antagonist, reduced the nicotine-induced BDNF over-expression in this cell line [28]. These findings suggest that nicotine-induced $\alpha 7 \mathrm{nAChR}$ stimulation is responsible for the expression of BDNF, which facilitates anterograde BDNF release to the striatum from cortices. A few studies have examined the effects of nicotine on retrograde BDNF release from corticostriatal nerve terminals [85]. Treatment with glutamate increases BDNF release in dendrites of cultured hippocampal neurons $[86,87]$.

The role played by BDNF in the regulation of nicotine-induced behaviors is not unequivocal. Growing evidence demonstrates BDNF in the striatum regulates nicotine-induced behaviors in ways that depend on the nature of nicotine exposure. Intra-striatal infusion of BDNF in rats augments increases in locomotor activity induced by repeated cocaine exposure [88,89]. Intra-NAc infusion of a TrkB antagonist reduced increases in cocaine-seeking caused by repeated exposure $[90,91]$. Systemic administration of a TrkB antagonist prior to repeated exposure to nicotine reduced nicotine intake, motivation, and reinstatement of nicotine-seeking [90]. In addition, infusion of exogenous BDNF after repeated exposure to nicotine increased new synapse formation in dendritic spines of the NAc and $\mathrm{CPu}$ [92], which suggests BDNF elevation after repeated exposure to nicotine increases synaptic strength in the striatum, and thus, enhances behavioral sensitization and nicotine-seeking behavior.

In contrast, intra-NAc infusion of BDNF during nicotine withdrawal decreased nicotine-induced increases in the reinstatement of self-administration in rats [93]. Intra-CPu infusion of BDNF prior to nicotine challenge reduced nicotine-induced increases in locomotor activity and stereotypy movement [94]. As observed for nicotine withdrawal, intra-NAc infusion of a TrkB antagonist during cocaine withdrawal before cue-induced reinstatement increased cocaine self-administration in rats [91]. Furthermore, cue-induced increase in reinstatement evoked by cocaine administration was decreased by intra-NAc infusion of BDNF during cocaine withdrawal [91]. Intra-PFC infusion of BDNF during early withdrawal reduced cocaine-induced increases in self-administration in rats [91,95-97]. These findings suggest that GABAergic activity decreases during nicotine withdrawal. However, BDNF infusion into the NAc lowered GABAergic activity to the basal level by activating BDNF-mediated TrkB signaling cascades [91,96,97], which is believed to be why exogenous BDNF infusion in brain followed by nicotine challenge reduces behavioral sensitization and nicotine-seeking as compared with nicotine challenge alone. This notion is supported in part by the finding that exogenous BDNF infusion in the PFC during early cocaine withdrawal increases ERK phosphorylation [97].

The effects of BDNF on glutamatergic neurotransmission, bidirectional BDNF releases in the striatum, behavioral sensitization after repeated exposure to nicotine, and the effects of nicotine withdrawal are summarized in Figure 1. Repeated exposure to nicotine increases glutamate release in the striatum by stimulating $\alpha 7 \mathrm{nAChRs}$, and dopamine may help to increase glutamate release [7-9]. In concert with increased glutamate release, BDNF release in the striatum is also enhanced by repeated exposure to nicotine $[16,19,20]$. Furthermore, this increase in BDNF release, resulting from anterograde and retrograde secretion, stimulates BDNF-mediated TrkB signaling cascades in GABAergic neurons, and thus, leading to psychomotor sensitization and nicotine-seeking behavior [21,69,74,91]. In contrast, 
BDNF infusion in the NAc returned hypo-activated GABAergic neurons during nicotine withdrawal to the basal level, which leads to downregulate nicotine challenge-induced increases in behaviors $[96,97]$. For this reason, infusion of BDNF during nicotine withdrawal might provide an effective means of controlling nicotine-induced relapse after withdrawal. Therefore, understanding of the molecular activities of BDNF and associated molecules in TrkB-mediated signaling cascades may aid the identification of potential therapeutic targets for the prevention of nicotine relapse.

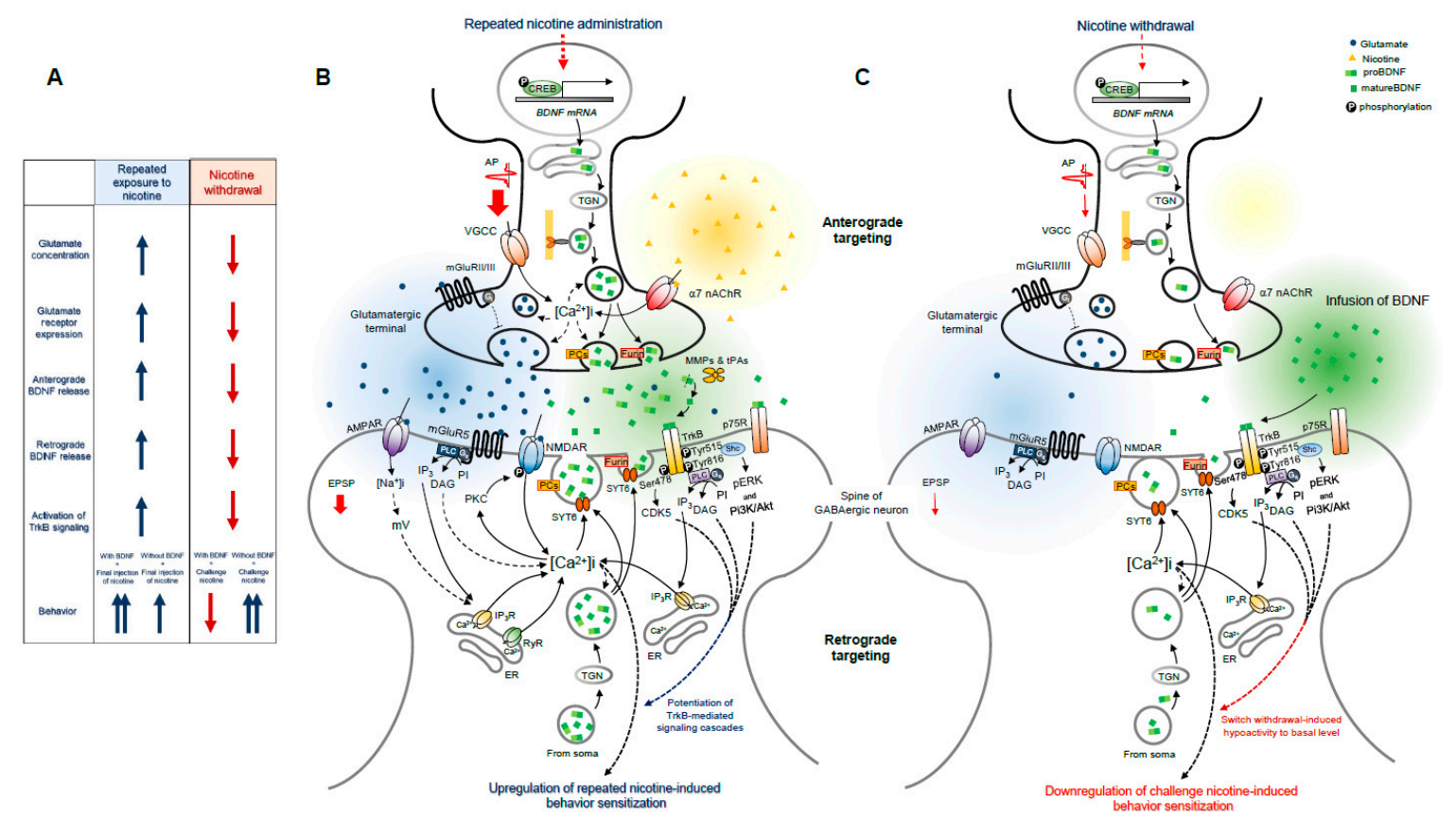

Figure 1. (A) Changes in glutamatergic neurotransmission, bidirectional BDNF release, BDNF-mediated signaling cascades, and behavioral sensitization after repeated exposure to nicotine and nicotine withdrawal. (B,C) Proposed cellular mechanisms underlying repeated nicotine exposure and nicotine withdrawal mediated effects in GABAergic neurons are schematically depicted and compared. Exogenous BDNF infusion into the striatum during nicotine withdrawal returned hypoactivated GABAergic neurons to the basal level by activating TrkB-linked signaling cascades $[91,96,97]$. Switched neural activity caused by BDNF does not alter after challenge nicotine administration. Putative interactions are discussed in the text. Solid and broken arrows represent direct and indirect stimulations of downstream molecules or behaviors, respectively. AP, action potential; $\left[\mathrm{Ca}^{2+}\right]$, $\mathrm{Ca}^{2+}$ concentration; EPSP, excitatory postsynaptic potential; $\mathrm{IP}_{3} \mathrm{R}$, inositol trisphosphate receptor; $\mathrm{mV}$, membrane potential; $\left[\mathrm{Na}^{+}\right], \mathrm{Na}^{+}$concentration; PKC, protein kinase C; RyR, ryanodine receptor; SYT, synpatotagamin; tPAs, tissue-plasminogen activators; VGCC, voltage-gated calcium channel.

Author Contributions: J.K., J.H.Y., and E.S.C. wrote and edited the paper; I.S.R., S.S., S.K., and J.K. drew the figure.

Funding: This work was supported by the National Research Foundation (grant no. NRF-2018R1A2B6003000) (to E.S.C.) and Ministry of Food and Drug Safety (grant no. 19183MFDS464) (to E.S.C.) of Korea.

Conflicts of Interest: The authors declare no conflict of interest.

\section{Abbreviations}

Akt

AMPAR

BDNF

CaRE

CDK5

$\mathrm{CPu}$
Protein Kinase B

Amino-3-hydroxy-5-methyl-4-isoxazolepropionic Acid Receptor

Brain-derived Neurotrophic Factor

$\mathrm{Ca}^{2+}$-responsive Element

Cell Division Protein Kinase 5

Caudate and Putamen 


\begin{tabular}{|c|c|}
\hline CREB & cAMP Response Element-binding Protein \\
\hline DAG & Diacylglycerol \\
\hline $\operatorname{Dh} \beta E$ & Dihydro- $\beta$-erythroidine \\
\hline ER & Endoplasmic Reticulum \\
\hline ERK & Extracellular-signal-regulated Kinase \\
\hline GABA & Gamma Amino-butyric Acid \\
\hline GLUNR2B & Ionotropic Glutamate Receptor Subtype 2B \\
\hline GTP & Guanosine-5'-triphosphate \\
\hline Htt & Huntingtin \\
\hline iGluRs & Ionotropic Glutamate Receptors \\
\hline IP3 & Inositol Trisphosphate \\
\hline KAR & Kainate Receptor \\
\hline MAGE & Melanoma-associated Antigen \\
\hline mGluRs & Metabotropic Glutamate Receptors \\
\hline MLA & Methyllycaconitine \\
\hline MMP & Matrix-metalloproteinases \\
\hline mTOR & Mechanistic Target of Rapamycin \\
\hline NAc & Nucleus Accumbens \\
\hline nAChRs & Nicotinic Acetylcholine Receptors \\
\hline NMDAR & $N$-methyl-D-aspartate Receptor \\
\hline NRAGE & MAGE Homologue \\
\hline NRIF & Neurotrophin Receptor-interacting Factor \\
\hline Ras & Ras GTPase \\
\hline p75NTR & p75 Neurotrophin Receptor \\
\hline PC & Proprotein Convertases \\
\hline PFC & Prefrontal Cortex \\
\hline PI3K & Phosphoinositide 3-kinases \\
\hline PIP2 & Phosphatidylinositol 4,5-bisphosphate \\
\hline PKC & Protein Kinase C \\
\hline PLC & Phospholipase C \\
\hline RhoGDI & Rho GDP-dissociation Inhibitor \\
\hline SC1 & Schwann Cell Factor 1 \\
\hline SH-SY5Y & Thrice-cloned Sub-line of Bone Marrow Biopsy-derived Line SK-N-SH \\
\hline She & SHC-transforming Protein 1 \\
\hline $\mathrm{SN}$ & Substantia Nigra \\
\hline SNARE & SNAP REceptor \\
\hline SYT6 & Synpatotagamin-6 \\
\hline TGN & Trans-Golgi Network \\
\hline tPA & Tissue-plasminogen Activator \\
\hline TrkB & Tropomyosin Receptor Kinase B \\
\hline VTA & Ventral Tegmental Area \\
\hline
\end{tabular}

\section{References}

1. Rigotti, N.A. Smoking cessation in patients with respiratory disease: Existing treatments and future directions. Lancet Respir. Med. 2013, 3, 241-250. [CrossRef]

2. Capelletto, E.; Rapetti, S.G.; Demichelis, S.; Galetta, D.; Catino, A.; Ricci, D.; Moretti, A.M.; Bria, E.; Pilotto, S.; Bruno, A.; et al. Final data of an Italian multicentric survey about counseling for smoking cessation in patients with diagnosis of a respiratory disease. Clin. Respir. J. 2018, 3, 1150-1159. [CrossRef] [PubMed]

3. Grady, S.R.; Salminen, O.; Laverty, D.C.; Whiteaker, P.; McIntosh, J.M.; Collins, A.C.; Marks, M.J. The subtypes of nicotinic acetylcholine receptors on dopaminergic terminals of mouse striatum. Biochem. Pharmacol. 2007, 8, 1235-1246. [CrossRef] [PubMed]

4. Livingstone, P.D.; Wonnacott, S. Nicotinic acetylcholine receptors and the ascending dopamine pathways. Biochem. Pharmacol. 2009, 7, 744-755. [CrossRef] [PubMed] 
5. Feduccia, A.A.; Chatterjee, S.; Bartlett, S.E. Neuronal nicotinic acetylcholine receptors: Neuroplastic changes underlying alcohol and nicotine addictions. Front. Mol. Neurosci. 2012, 5, 83. [CrossRef] [PubMed]

6. Howe, W.M.; Young, D.A.; Bekheet, G.; Kozak, R. Nicotinic receptor subtypes differentially modulate glutamate release in the dorsal medial striatum. Neurochem. Int. 2016, 100, 30-34. [CrossRef] [PubMed]

7. Kalivas, P.W.; Lalumiere, R.T.; Knackstedt, L.; Shen, H. Glutamate transmission in addiction. Neuropharmacology 2009, 56 (Suppl. 1), 169-173. [CrossRef] [PubMed]

8. Gerfen, C.R.; Surmeier, D.J. Modulation of striatal projection systems by dopamine. Annu. Rev. Neurosci. 2011, 34, 441-466. [CrossRef]

9. Francesco, P.; Francesco, C.; Michele, Z.; Gotti, C. Nicotinic, glutamatergic and dopaminergic synaptic transmission and plasticity in the mesocorticolimbic system: Focus on nicotine effects. Prog. Neurobiol. 2015, 124, 1-27. [CrossRef]

10. Ahn, S.M.; Choe, E.S. Activation of group I metabotropic glutamate receptors increases serine phosphorylation of GluR1 alpha-amino-3-hydroxy-5-methylisoxazole-4-propionic acid receptors in the rat dorsal striatum. J. Pharmacol. Exp. Ther. 2009, 3, 1117-1126. [CrossRef]

11. Oh, J.H.; Yang, J.H.; Ahn, S.M.; Youn, B.; Choi, B.T.; Wang, J.Q.; Choe, E.S. Activation of protein kinase C is required for AMPA receptor GluR1 phosphorylation at serine 845 in the dorsal striatum following repeated cocaine administration. Psychopharmacology 2013, 3, 437-445. [CrossRef] [PubMed]

12. Seo, S.Y.; Oh, J.H.; Choe, E.S. Protein kinase G increases AMPA receptor GluR1 phosphorylation at serine 845 after repeated cocaine administration in the rat nucleus accumbens. Neurosci. Lett. 2013, 544, 147-151. [CrossRef] [PubMed]

13. Ryu, I.S.; Kim, J.; Seo, S.Y.; Yang, J.H.; Oh, J.H.; Lee, D.K.; Cho, H.W.; Yoon, S.S.; Seo, J.W.; Chang, S.; et al. Behavioral changes after nicotine challenge are associated with $\alpha 7$ nicotinic acetylcholine receptor-stimulated glutamate release in the rat dorsal striatum. Sci. Rep. 2017, 1, 15009. [CrossRef] [PubMed]

14. Ryu, I.S.; Kim, J.; Seo, S.Y.; Yang, J.H.; Oh, J.H.; Lee, D.K.; Cho, H.W.; Lee, K.; Yoon, S.S.; Seo, J.W.; et al. Repeated Administration of Cigarette Smoke Condensate Increases Glutamate Levels and Behavioral Sensitization. Front. Behav. Neurosci. 2018, 12, 47. [CrossRef] [PubMed]

15. Correll, J.A.; Noel, D.M.; Sheppard, A.B.; Thompson, K.N.; Li, Y.; Yin, D.; Brown, R.W. Nicotine sensitization and analysis of brain-derived neurotrophic factor in adolescent beta-arrestin-2 knockout mice. Synapse 2009, 6, 510-519. [CrossRef] [PubMed]

16. Leão, R.M.; Cruz, F.C.; Carneiro-de-Oliveira, P.E.; Rossetto, D.B.; Valentini, S.R.; Zanelli, C.F.; Planeta, C.S. Enhanced nicotine-seeking behavior following pre-exposure to repeated cocaine is accompanied by changes in BDNF in the nucleus accumbens of rats. Pharmacol. Biochem. Behav. 2013, 104, 169-176. [CrossRef]

17. Perna, M.K.; Brown, R.W. Adolescent nicotine sensitization and effects of nicotine on accumbal dopamine release in a rodent model of increased dopamine D2 receptor sensitivity. Behav. Brain. Res. 2013, 242, 102-109. [CrossRef]

18. Kittikun, V.; Sukumal, C. Activation of group I metabotropic glutamate receptors leads to brain-derived neurotrophic factor expression in rat C6 cells. Neurosci. Lett. 2019, 2, 127-130. [CrossRef]

19. Kivinummi, T.; Kaste, K.; Rantamaki, T.; Castrén, E.; Ahtee, L. Alterations in BDNF and phospho-CREB levels following chronic oral nicotine treatment and its withdrawal in dopaminergic brain areas of mice. Neurosci. Lett. 2011, 2, 108-112. [CrossRef]

20. Aydin, C.; Oztan, O.; Isgor, C. Nicotine-induced anxiety-like behavior in a rat model of the novelty-seeking phenotype is associated with long-lasting neuropeptidergic and neuroplastic adaptations in the amygdala: Effects of the cannabinoid receptor 1 antagonist AM251. Neuropharmacology 2012, 8, 1335-1345. [CrossRef]

21. Patapoutian, A.; Reichardt, L.F. Trk receptors: Mediators of neurotrophin action. Curr. Opin. Neurobiol. 2001, 3, 272-280. [CrossRef]

22. Lu, B. BDNF and activity-dependent synaptic modulation. Learn. Mem. 2003, 2, 86-98. [CrossRef] [PubMed]

23. Machaalania, R.; Chen, H. Brain derived neurotrophic factor (BDNF), its tyrosine kinase receptor B (TrkB) and nicotine. Neurotoxicology 2018, 65, 186-195. [CrossRef] [PubMed]

24. Yager, L.M.; Garcia, A.F.; Wunsch, A.M.; Ferguson, S.M. The ins and outs of the striatum: Role in drug addiction. Neuroscience 2015, 301, 529-541. [CrossRef] [PubMed]

25. Kim, H.J.; Lee, J.H.; Yun, K.; Kim, J.H. Alterations in Striatal Circuits Underlying Addiction-Like Behaviors. Mol. Cells 2017, 6, 379-385. [CrossRef] [PubMed] 
26. Grilli, M.; Pittaluga, A.; Merlo-Pich, E.; Marchi, M. NMDA-mediated modulation of dopamine release is modified in rat prefrontal cortex and nucleus accumbens after chronic nicotine treatment. J. Neurochem. 2009, 2, 408-416. [CrossRef] [PubMed]

27. Chen, Y.H.; Lin, B.J.; Hsieh, T.H.; Kuo, T.T.; Miller, J.; Chou, Y.C.; Huang, E.Y.; Hoffer, B.J. Differences in Nicotine Encoding Dopamine Release between the Striatum and Shell Portion of the Nucleus Accumbens. Cell Transpl. 2019, 3, 248-261. [CrossRef]

28. Ehlinger, D.G.; Burke, J.C.; McDonald, C.G.; Smith, R.F.; Bergstrom, H.C. Nicotine-induced and D1-receptor-dependent dendritic remodeling in a subset of dorsolateral striatum medium spiny neurons. Neuroscience 2017, 356, 242-254. [CrossRef]

29. Marshall, D.L.; Redfern, P.H.; Wonnacott, S. Presynaptic nicotinic modulation of dopamine release in the three ascending pathways studied by in vivo microdialysis: Comparison of naive and chronic nicotine-treated rats. J. Neurochem. 1997, 4, 1511-1519. [CrossRef]

30. Reid, M.S.; Fox, L.; Ho, L.B.; Berger, S.P. Nicotine stimulation of extracellular glutamate levels in the nucleus accumbens: Neuropharmacological characterization. Synapse 2000, 2, 129-136. [CrossRef]

31. Gotti, C.; Clementi, F. Neuronal nicotinic receptors: From structure to pathology. Prog. Neurobiol. 2004, 6, 363-396. [CrossRef]

32. Albuquerque, E.X.; Pereira, E.F.; Alkondon, M.; Rogers, S.W. Mammalian nicotinic acetylcholine receptors: From structure to function. Physiol. Rev. 2009, 1, 73-120. [CrossRef] [PubMed]

33. Hurst, R.; Rollema, H.; Bertrand, D. Nicotinic acetylcholine receptors: From basic science to therapeutics. Pharmacol. Ther. 2013, 1, 22-54. [CrossRef] [PubMed]

34. Dani, J.A.; Bertrand, D. Nicotinic acetylcholine receptors and nicotinic cholinergic mechanisms of the central nervous system. Annu. Rev. Pharmacol. Toxicol. 2007, 47, 699-729. [CrossRef] [PubMed]

35. Mansvelder, H.D.; McGehee, D.S. Cellular and synaptic mechanisms of nicotine addiction. J. Neurobiol. 2002, 4, 606-617. [CrossRef] [PubMed]

36. Changeux, J.P. Nicotine addiction and nicotinic receptors: Lessons from genetically modified mice. Nat. Rev. Neurosci. 2010, 6, 389-401. [CrossRef] [PubMed]

37. Shameem, M.; Patel, A.B. Glutamatergic and GABAergic metabolism in mouse brain under chronic nicotine exposure: Implications for addiction. PLoS ONE 2012, 7, e41824. [CrossRef]

38. Couey, J.J.; Meredith, R.M.; Spijker, S.; Poorthuis, R.B.; Smit, A.B.; Brussaard, A.B.; Mansvelder, H.D. Distributed network actions by nicotine increase the threshold for spike timing-dependent plasticity in prefrontal cortex. Neuron 2007, 1, 73-87. [CrossRef]

39. Puddifoot, C.A.; Wu, M.; Sung, R.J.; Joiner, W.J. Ly6h regulates trafficking of alpha7 nicotinic acetylcholine receptors and nicotine-induced potentiation of glutamatergic signaling. J. Neurosci. 2015, 8, 3420-3430. [CrossRef]

40. Jackson, A.; Papke, R.L.; Damaj, M.I. Pharmacological modulation of the $\alpha 7$ nicotinic acetylcholine receptor in a mouse model of mecamylamine-precipitated nicotine withdrawal. Psychopharmacology 2018, 7, 1897-1905. [CrossRef]

41. Brunzell, D.H.; McIntosh, J.M. Alpha7 nicotinic acetylcholine receptors modulate motivation to self-administer nicotine: Implications for smoking and schizophrenia. Neuropsychopharmacology 2012, 5, 1134-1143. [CrossRef] [PubMed]

42. D'Souza, M.S.; Markou, A. The "stop" and "go" of nicotine dependence: Role of GABA and glutamate. Cold Spring Harb. Perspect. Med. 2013, 6, a012146. [CrossRef] [PubMed]

43. Kew, J.N.; Kemp, J.A. Ionotropic and metabotropic glutamate receptor structure and pharmacology. Psychopharmacology 2005, 1, 4-29. [CrossRef] [PubMed]

44. Ferraguti, F.; Shigemoto, R. Metabotropic glutamate receptors. Cell Tissue Res. 2006, 2, 483-504. [CrossRef] [PubMed]

45. Traynelis, S.F.; Wollmuth, L.P.; McBain, C.J.; Menniti, F.S.; Vance, K.M.; Ogden, K.K.; Hansen, K.B.; Yuan, H.; Myers, S.J.; Dingledine, R. Glutamate receptor ion channels: Structure, regulation, and function. Pharmacol. Rev. 2010, 3, 405-496. [CrossRef] [PubMed]

46. Paoletti, P.; Bellone, C.; Zhou, Q. NMDA receptor subunit diversity: Impact on receptor properties, synaptic plasticity and disease. Nat. Rev. Neurosci. 2013, 6, 383-400. [CrossRef] 
47. Wang, F.; Chen, H.; Steketee, J.D.; Sharp, B.M. Upregulation of ionotropic glutamate receptor subunits within specific mesocorticolimbic regions during chronic nicotine self-administration. Neuropsychopharmacology 2007, 1, 103-109. [CrossRef]

48. Nakajima, A.; Kinugasa, Y.; Torii, J.; Hishinuma, T.; Tomioka, Y.; Yamada, K.; Yamakuni, T. Repeated treatment with nicotine induces phosphorylation of NMDA receptor NR2B subunit in the brain regions involved in behavioral sensitization. Neurosci. Lett. 2012, 2, 133-138. [CrossRef]

49. Ávila-Ruiz, T.; Carranza, V.; Gustavo, L.L.; Limón, D.I.; Martínez, I.; Flores, G.; Flores-Hernández, J. Chronic administration of nicotine enhances NMDA-activated currents in the prefrontal cortex and core part of the nucleus accumbens of rats. Synapse 2014, 6, 248-256. [CrossRef]

50. Kenny, P.J.; Chartoff, E.; Roberto, M.; Carlezon, W.A., Jr.; Markou, A. NMDA receptors regulate nicotine-enhanced brain reward function and intravenous nicotine self-administration: Role of the ventral tegmental area and central nucleus of the amygdala. Neuropsychopharmacology 2009, 2, 266-281. [CrossRef]

51. Bespalov, A.Y.; Dravolina, O.A.; Sukhanov, I.; Zakharova, E.; Blokhina, E.; Zvartau, E.; Danysz, W.; van Heeke, G.; Markou, A. Metabotropic glutamate receptor (mGluR5) antagonist MPEP attenuated cueand schedule-induced reinstatement of nicotine self-administration behavior in rats. Neuropharmacology 2005, 49, 167-178. [CrossRef] [PubMed]

52. Paterson, N.E.; Markou, A. The metabotropic glutamate receptor 5 antagonist MPEP decreased break points for nicotine, cocaine and food in rats. Psychopharmacology 2005, 1, 255-261. [CrossRef] [PubMed]

53. Tronci, V.; Vronskaya, S.; Montgomery, N.; Mura, D.; Balfour, D.J. The effects of the mGluR5 receptor antagonist 6-methyl-2-(phenylethynyl)-pyridine (MPEP) on behavioral responses to nicotine. Psychopharmacology 2010, 1, 33-42. [CrossRef] [PubMed]

54. Yararbas, G.; Keser, A.; Kanit, L.; Pogun, S. Nicotine-induced conditioned place preference in rats: Sex differences and the role of mGluR5 receptors. Neuropharmacology 2010, 2, 374-382. [CrossRef] [PubMed]

55. Kenny, P.J.; Markou, A. The ups and downs of addiction: Role of metabotropic glutamate receptors. Trends Pharmacol. Sci. 2004, 5, 265-272. [CrossRef] [PubMed]

56. Mao, L.; Guo, M.; Jin, D.; Xue, B.; Wang, J.Q. Group III metabotropic glutamate receptors and drug addiction. Front. Med. 2013, 4, 445-451. [CrossRef] [PubMed]

57. Xi, Z.X.; Baker, D.A.; Shen, H.; Carson, D.S.; Kalivas, P.W. Group II metabotropic glutamate receptors modulate extracellular glutamate in the nucleus accumbens. J. Pharmacol. Exp. Ther. 2002, 1, $162-171$. [CrossRef] [PubMed]

58. Li, X.; D’Souza, M.S.; Niño, A.M.; Doherty, J.; Cross, A.; Markou, A. Attenuation of nicotine-taking and nicotine-seeking behavior by the mGlu2 receptor positive allosteric modulators AZD8418 and AZD8529 in rats. Psychopharmacology 2016, 10, 1801-1814. [CrossRef] [PubMed]

59. Volkmar, L.; Tanja, B. Mechanisms, locations, and kinetics of synaptic BDNF secretion: An update. Neurosci. Res. 2009, 1, 11-22. [CrossRef]

60. Chen, K.W.; Chen, L. Epigenetic regulation of BDNF gene during development and diseases. Int. J. Mol. Sci. 2017, 18, 571. [CrossRef]

61. Benarroch, E.E. Brain-derived neurotrophic factor: Regulation, effects, and potential clinical relevance. Neurology 2015, 16, 1693-1704. [CrossRef] [PubMed]

62. Thomas, G. Furin at the cutting edge: From protein traffic to embryogenesis and disease. Nat. Rev. Mol. Cell Biol. 2002, 10, 753-766. [CrossRef] [PubMed]

63. Mulcahy, L.R.; Nillni, E.A. Discovery of new peptides from old prohormones: Insights for energy balance and beyond. Front. Biosci. 2007, 12, 3545-3553. [CrossRef] [PubMed]

64. Gauthier, L.R.; Charrin, B.C.; Borrell-Pages, M.; Dompierre, J.P.; Rangone, H.; Cordelières, F.P.; De Mey, J.; MacDonald, M.E.; Lessmann, V.; Humbert, S.; et al. Huntingtin controls neurotrophic support and survival of neurons by enhancing BDNF vesicular transport along microtubules. Cell 2004, 1, 127-138. [CrossRef] [PubMed]

65. Matsuda, N.; Lu, H.; Fukata, Y.; Noritake, J.; Gao, H.; Mukherjee, S.; Nemoto, T.; Fukata, M.; Poo, M.M. Differential activity dependent secretion of brain-derived neurotrophic factor from axon and dendrite. J. Neurosci. 2009, 45, 14185-14198. [CrossRef]

66. Kwinter, D.M.; Lo, K.; Mafi, P.; Silverman, M.A. Dynactin regulates bidirectional transport of dense-core vesicles in the axon and dendrites of cultured hippocampal neurons. Neuroscience 2009, 4, 1001-1010. [CrossRef] [PubMed] 
67. Lee, R.; Kermani, P.; Teng, K.K.; Hempstead, B.L. Regulation of cell survival by secreted proneurotrophins. Science 2001, 5548, 1945-1948. [CrossRef]

68. Nikulina, E.M.; Lacagnina, M.J.; Fanous, S.; Wang, J.; Hammer, R.P., Jr. Intermittent social defeat stress enhances mesocorticolimbic $\triangle \mathrm{FosB} / \mathrm{BDNF}$ co-expression and persistently activates corticotegmental neurons: Implication for vulnerability to psychostimulants. Neuroscience 2012, 212, 38-48. [CrossRef]

69. Hartmann, M.; Heumann, R.; Lessmann, V. Synaptic secretion of BDNF after high-frequency stimulation of glutamatergic synapses. EMBO J. 2001, 21, 5887-5897. [CrossRef]

70. Alder, J.; Thakker-Varia, S.; Crozier, R.A.; Shaheen, A.; Plummer, M.R.; Black, I.B. Early presynaptic and late postsynaptic components contribute independently to brain-derived neurotrophic factor-induced synaptic plasticity. J. Neurosci. 2005, 12, 3080-3085. [CrossRef]

71. Park, H.; Popescu, A.; Poo, M.M. Essential Role of Presynaptic NMDA Receptors in Activity-Dependent BDNF Secretion and Corticostriatal LTP. Neuron 2014, 5, 1009-1022. [CrossRef] [PubMed]

72. Hammond, C. Cellular and molecular neurobiology. In The Metabotropic Glutamate Receptors; Bhave, G., Gereau, R., Eds.; Academic Press: Amsterdam, The Netherland, 2003; pp. 314-326.

73. Wong, Y.H.; Lee, C.M.; Xie, W.; Cui, B.; Poo, M.M. Activity-dependent BDNF release via endocytic pathways is regulated by synaptotagmin-6 and complexin. Proc. Natl. Acad. Sci. USA 2015, 32, E4475-E4484. [CrossRef] [PubMed]

74. Besusso, D.; Geibel, M.; Kramer, D.; Schneider, T.; Pendolino, V.; Picconi, B.; Calabresi, P.; Bannerman, D.M.; Minichiello, L. BDNF-TrkB signaling in striatopallidal neurons controls inhibition of locomotor behavior. Nat. Commun. 2013, 4, 2031. [CrossRef] [PubMed]

75. Sasi, M.; Vignoli, B.; Canossa, M.; Blum, R. Neurobiology of local and intercellular BDNF signaling. Pflugers Arch. 2017, 5-6, 593-610. [CrossRef]

76. Panja, D.; Bramham, C.R. BDNF mechanisms in late LTP formation: A synthesis and breakdown. Neuropharmacology 2014, 76 Pt C, 664-676. [CrossRef]

77. Panja, D.; Kenney, J.W.; D'Andrea, L.; Zalfa, F.; Vedeler, A.; Wibrand, K.; Fukunaga, R.; Bagni, C.; Proud, C.G.; Bramham, C.R. Two-stage translational control of dentate gyrus LTP consolidation is mediated by sustained BDNF-TrkB signaling to MNK. Cell Rep. 2014, 4, 1430-1445. [CrossRef]

78. D'Amore, D.E.; Tracy, B.A.; Parikh, V. Exogenous BDNF facilitates strategy set-shifting by modulating glutamate dynamics in the dorsal striatum. Neuropharmacology 2013, 75, 312-323. [CrossRef]

79. Teng, H.K.; Teng, K.K.; Lee, R.; Wright, S.; Tevar, S.; Almeida, R.D.; Kermani, P.; Torkin, R.; Chen, Z.Y.; Lee, F.S.; et al. ProBDNF induces neuronal apoptosis via activation of a receptor complex of p75NTR and sortilin. J. Neurosci. 2005, 22, 5455-5463. [CrossRef]

80. Yang, J.; Harte-Hargrove, L.C.; Siao, C.J.; Marinic, T.; Clarke, R.; Ma, Q.; Jing, D.; Lafrancois, J.J.; Bath, K.G.; Mark, W.; et al. ProBDNF negatively regulates neuronal remodeling, synaptic transmission, and synaptic plasticity in hippocampus. Cell Rep. 2014, 3, 796-806. [CrossRef]

81. Altar, C.A.; DiStefano, P.S. Neurotrophin trafficking by anterograde transport. Trends Neurosci. 1998, 10, 433-437. [CrossRef]

82. Serres, F.; Carney, S.L. Nicotine regulates SH-SY5Y neuroblastoma cell proliferation through the release of brain-derived neurotrophic factor. Brain Res. 2006, 1, 36-42. [CrossRef] [PubMed]

83. Johansson, J.; Formaggio, E.; Fumagalli, G.; Chiamulera, C. Choline up-regulates BDNF and down-regulates TrkB neurotrophin receptor in rat cortical cell culture. Neuroreport 2009, 9, 828-832. [CrossRef] [PubMed]

84. Xiaoyu, W. The exposure to nicotine affects expression of brain-derived neurotrophic factor (BDNF) and nerve growth factor (NGF) in neonate rats. Neurol Sci. 2015, 2, 289-295. [CrossRef] [PubMed]

85. Reimers, J.M.; Loweth, J.A.; Wolf, M.E. BDNF contributes to both rapid and homeostatic alterations in AMPA receptor surface expression in nucleus accumbens medium spiny neurons. Eur. J. Neurosci. 2014, 7, 1159-1169. [CrossRef] [PubMed]

86. Magby, J.P.; Bi, C.; Chen, Z.Y.; Lee, F.S.; Plummer, M.R. Single-cell characterization of retrograde signaling by brain-derived neuro- trophic factor. J. Neurosci. 2006, 26, 13531-13536. [CrossRef] [PubMed]

87. Crozier, R.A.; Bi, C.; Han, Y.R.; Plummer, M.R. BDNF modulation of NMDA receptors is activity dependent. J. Neurophysiol. 2008, 6, 3264-3274. [CrossRef] [PubMed]

88. Horger, B.A.; Iyasere, C.A.; Berhow, M.T.; Messer, C.J.; Nestler, E.J.; Taylor, J.R. Enhancement of locomotor activity and conditioned reward to cocaine by brain-derived neurotrophic factor. J. Neurosci. 1999, 10, 4110-4122. [CrossRef] 
89. Williams, S.N.; Undieh, A.S. Dopamine D1-like receptor activation induces brain-derived neurotrophic factor protein expression. Neuroreport 2009, 6, 606-610. [CrossRef]

90. Verheij, M.M.; Vendruscolo, L.F.; Caffino, L.; Giannotti, G.; Cazorla, M.; Fumagalli, F.; Riva, M.A.; Homberg, J.R.; Koob, G.F.; Contet, C. Systemic Delivery of a Brain-Penetrant TrkB Antagonist Reduces Cocaine Self-Administration and Normalizes TrkB Signaling in the Nucleus Accumbens and Prefrontal Cortex. J. Neurosci. 2016, 31, 8149-8159. [CrossRef]

91. Bobadilla, A.C.; Garcia-Keller, C.; Chareunsouk, V.; Hyde, J.; Camacho, D.M.; Heinsbroek, J.A.; Kalivas, P.W. Accumbens brain-derived neurotrophic factor (BDNF) transmission inhibits cocaine seeking. Addict. Biol. 2018. [CrossRef]

92. Gottmann, K.; Mittmann, T.; Lessmann, V. BDNF signaling in the formation, maturation and plasticity of glutamatergic and GABAergic synapses. Exp. Brain Res. 2009, 3-4, 203-234. [CrossRef] [PubMed]

93. Pickens, C.L.; Airavaara, M.; Theberge, F.; Fanous, S.; Hope, B.T.; Shaham, Y. Neurobiology of the incubation of drug craving. Trends. Neurosci. 2011, 8, 411-420. [CrossRef] [PubMed]

94. Kim, J.; Yang, J.H.; Ryu, I.S.; Seo, S.Y.; Son, S.; Kim, S.; Choe, E.S. Challenge nicotine upregulates mature-BDNF expression in the dorsal striatum via mGluR5-mediated MMP2/9 activation. (unpublished; manuscript in preparation).

95. Berglind, W.J.; Whitfield, T.W., Jr.; LaLumiere, R.T.; Kalivas, P.W.; McGinty, J.F. A single intra-PFC infusion of BDNF pre- vents cocaine-induced alterations in extracellular glutamate within the nucleus accumbens. J. Neurosci. 2009, 12, 3715-3719. [CrossRef] [PubMed]

96. Sun, W.L.; Coleman, N.T.; Zelek-Molik, A.; Barry, S.M.; Whitfield, T.W., Jr.; McGinty, J.F. Relapse to cocaine-seeking after abstinence Is regulated by cAMP-dependent protein kinase A in the prefrontal cortex. Addict. Biol. 2014, 1, 77-86. [CrossRef] [PubMed]

97. Go, B.S.; Barry, S.M.; McGinty, J.F. Glutamatergic neurotransmission in the prefrontal cortex mediates the suppressive effect of intra-prelimbic cortical infusion of BDNF on cocaine-seeking. Eur. Neuropsychopharmacol. 2016, 12, 1989-1999. [CrossRef] [PubMed] 